\title{
Transatlantica
}

Revue d'études américaines. American Studies Journal

\section{Bernd Herzogenrath (ed). From Virgin Land to Disney World: Nature and Its Discontents in the U.S.A. of Yesterday and Today. Critical Studies, Vol. 15.}

Amsterdam/New York : Editions Rodopi, 2001. 432 pp.

\section{Thomas Carmichael}

\section{CpenEdition}

\section{Journals}

Édition électronique

URL : http://journals.openedition.org/transatlantica/856

DOI : 10.4000/transatlantica.856

ISSN : $1765-2766$

Éditeur

AFEA

Référence électronique

Thomas Carmichael, « Bernd Herzogenrath (ed). From Virgin Land to Disney World: Nature and Its Discontents in the U.S.A. of Yesterday and Today. Critical Studies, Vol. 15. », Transatlantica [En ligne], 1 । 2005, mis en ligne le 22 avril 2006, consulté le 29 avril 2021. URL : http://journals.openedition.org/ transatlantica/856 ; DOI : https://doi.org/10.4000/transatlantica.856

Ce document a été généré automatiquement le 29 avril 2021

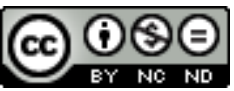

Transatlantica - Revue d'études américaines est mis à disposition selon les termes de la licence Creative Commons Attribution - Pas d'Utilisation Commerciale - Pas de Modification 4.0 International. 


\title{
Bernd Herzogenrath (ed). From Virgin Land to Disney World : Nature and Its Discontents in the U.S.A. of Yesterday and Today. Critical Studies, Vol. 15.
}

Amsterdam/New York : Editions Rodopi, 2001. 432 pp.

\author{
Thomas Carmichael
}

1 The essays in this volume present diverse readings of the place of nature in American culture from the European arrival to the postmodern period. Theoretically informed and richly considered, these essays can loosely be divided into those which take a specific historical moment or representation as their object-Thomas Cole's Hudson river paintings, Poe's Julius Rodman, antinomianism in the 1960s, Sam Peckinpah,'s The Wild Bunch, or the cultural logic of the Las Vegas strip, to cite just a few examples-and those that are directed at the construction of nature in American intellectual history and in the context of contemporary theory, from the Kantian sublime and early American culture to Tocqueville and Baudrillard and the American scene, and the inhuman in Lyotard and nature. Moreover, as the editor of the collection, Bernd Herzogenrath, explains, this volume initially grew out of an European Association of American Studies workshop on "Re-interpretations of Freud's Civilization Thesis," and many of the essays reflect this original orientation in their deft rethinking of Freud's Civilization and Its Discontents in the specific context of American cultural studies.

One of the real strengths of this volume is the originality that characterizes those essays that are devoted to specific cultural artifacts or practices. One might reasonably expect that any collection devoted to American studies and nature would include reflections on Disney's version of nature, but what is particularly welcome about the essays on Disney included here is the way in which they explore the full complexity of the mass cultural imagination. In her consideration of Disney's Pocohantas and 
postmodern ethics, for example, Roxanna Preda makes an effective case for reading the film as a representation of ecofeminism; similarly, Jennifer Cypher and Eric Higgs, in their decipherment of the semiotics of the Wilderness Lodge resort at Disney World, manage to insist equally that the hotel's architecture both colonizes nature and stands apart from it as an instance of pure hyperreality. The ironies of constructing nature are also the subject of Laura Barrett and Daniel White's "Postmodern Ecology and the Kissimmee River Restoration Project," an essay that works well with Tim Collins's contribution on the social organization of a postindustrial nature project in the urban brownfields of Pittsburgh, and with Natasha Dow Schüll's "Fantasies of Nature in Las Vegas," in which she recounts the complex genealogy of casino construction and representation on the Las Vegas strip. In a similar vein, Bernd Herzogenrath's essay on Thomas Cole's idealization of nature in the early nineteenth century and Megan C. McShane's article on Merle Laderman Ukeles, artist-in-residence at the New York City Department of Sanitation, are particularly valuable for their very different considerations of the social functions of art and the representation of nature. The other major thematic thread that runs through the essays in this collection is the relation between the representation of nature and the construction of the American subject. This is the focus of Lee Rozelle's essay on Poe's The Journal of Julias Rodman and Isabella Bird's A Lady's Life in the Rocky Mountains, and it informs Bill Freind's discussion of nature in the poetry of Charles Olson. The social construction of the self is of course central to William Cummings's essay on tattooing in recent American culture, and it is equally important to the expansive argument that David R. Willliams presents about the politics of oppositionality in the culture of the 1960s. The construction of the American subject is also an important aspect of the contemporary theoretical discussions included in this volume, as reflected in James Kirwan's meditation on Lyotard, the sublime, and nature, and in Adrian Ivakhiv's Foucauldian reading of posthumanist trends in environmental and cultural discourses.

From Virgin Land to Disney World is an engaging contribution the study of the construction and representation of nature in American studies, American literature, and American culture. These essays provide both fresh readings of celebrated artifacts and original considerations of overlooked and unwisely neglected moments in American culture and intellectual history. Bernd Herzogenrath has assembled a valuable collection, judiciously compiled and edited.

\section{INDEX}

Thèmes : Recensions

\section{AUTEUR}

THOMAS CARMICHAEL

University of Western Ontario 